\title{
Effect of A23187 or angiotensin II on ovarian metalloproteinase inhibitors and steroidogenesis in rats
}

\author{
C. M. Cannon ${ }^{1}$, S. C. Keeble ${ }^{2}$ and T. E. Curry, $\mathrm{Jr}^{1,2 *}$ \\ Departments of ${ }^{\mathrm{I}}$ Anatomy \& Neurobiology, and ${ }^{2}$ Obstetrics \& Gynecology, University of Kentucky, \\ Lexington, $K Y 40536, U S A$
}

\begin{abstract}
The present study examined the effect of the calcium ionophore A23187 or angiotensin II (AII) on the expression of ovarian metalloproteinase inhibitor and activity in rat granulosa cells and intact ovaries. Granulosa cells were collected from rats primed with pregnant mares' serum gonadotrophin (PMSG) and cultured for $24 \mathrm{~h}$ with A23187, AIl, or the AII receptor antagonist, saralasin, in the presence or absence of $\mathrm{LH}$. Metalloproteinase inhibitor activity and progesterone concentrations were determined in the media. In the A23187 experiment, addition of A23187 to granulosa cells, cultured without $\mathrm{LH}$, decreased inhibitor activity, especially at the concentrations of 10 and $100 \mu \mathrm{mol} \mathrm{l}^{-1}$ (decrease to $33 \pm 7 \%$ and $31 \pm 5 \%$ of control culture values, respectively). Addition of $\mathrm{LH}$ to the media increased inhibitor activity $3.04 \pm 0.39$ times compared with the control; however, A23187 (10 and $100 \mu \mathrm{mol} \mathrm{l}^{-1}$ ), in the presence of $\mathrm{LH}$, decreased inhibitor activity by approximately $67 \%$. The ionophore had disparate effects on progesterone production. Without LH, A23187 increased progesterone production by $2.96 \pm 0.47$ times at $10 \mu \mathrm{mol} \mathrm{l}^{-1}$ and by $5.53 \pm 0.65$ times at $100 \mu \mathrm{mol} 1^{-1}$. However, in LH-stimulated cells, progesterone was inhibited by A23187 at 1 and $10 \mu \mathrm{mol} \mathrm{l}^{-1}$ but was unchanged at $100 \mu \mathrm{mol} \mathrm{l}^{-1}$. In the angiotensin experiment, addition of AII $\left(0-10000 \mathrm{nmol} \mathrm{l}^{-1}\right)$ or saralasin $\left(1 \mu \mathrm{mol} \mathrm{l} l^{-1}\right)$ did not affect inhibitor activity or progesterone concentrations compared with control values in the absence or presence of LH. For the angiotensin experiment in vivo, PMSG-primed rats were injected with hCG followed by saralasin $\left(10 \mathrm{mmol}^{-1}\right) 1$ or $3 \mathrm{~h}$ later and killed at 4,8 , or $12 \mathrm{~h}$ after hCG. Expression of the ovarian tissue inhibitor of metalloproteinase-1 (TIMP-1) increased by 1.7 times at $4 \mathrm{~h}, 3.3$ times at $8 \mathrm{~h}$, and 3.0 times at $12 \mathrm{~h}$ after hCG compared with values in ovaries collected at the time of hCG injection. Administration of saralasin at I or $3 \mathrm{~h}$ after hCG had no effect on expression of TIMP-I or on serum concentrations of progesterone or oestradiol. In summary, A23187 decreased granulosa cell-derived inhibitor activity, whereas AII had no effect. We propose that calcium may play a role in modulating proteolysis associated with ovulation, while AII does not appear to regulate ovarian metalloproteinase inhibitor activity.
\end{abstract}

\section{Introduction}

Ovulation is a dynamic process that involves remodelling of the wall of the Graafian follicle resulting in eventual follicular rupture and expulsion of the oocyte. The ovulatory process is set in motion by the preovulatory LH surge which, in turn, stimulates a biochemical cascade associated with follicular rupture (Espey and Lipner, 1994). One LH-mediated event in the ovulatory pathway is the stimulation of proteolytic enzymes, such as the matrix metalloproteinases collagenase and gelatinase, and their associated inhibitors. It has been suggested that proteolysis in the ovulatory process results in degradation of the apical follicular connective tissue, thereby facilitating oocyte release (Espey and Lipner, 1994).

* Reprint requests and correspondence.

Received 16 December 1996.
Although many of the LH-stimulated pathways have been elucidated, the precise mechanisms by which LH induces proteolytic enzyme activity and subsequent ovulation are enigmatic. Both calcium and the ovarian renin-angiotensin system (OVRAS) are stimulated by LH and modulate follicular rupture (Pellicer et al., 1988; Kuo et al., 1991; Peterson et al., 1993a). In the ovary, calcium affects steroidogenesis and stimulates oocyte release potentially by inducing contractility of thecal smooth muscle (Martin and Talbot, 1981; Welsh et al., 1984; Kitai et al., 1985; Veldhuis and Denver, 1986; Hylka and DiZegera, 1990). The stimulatory role of calcium in ovulation is evident from studies demonstrating that administration of calcium channel blockers inhibits oocyte release in vitro (Kitai et al., 1985).

For the OVRAS, investigators have postulated that angiotensin II (AII), a component of the renin-angiotensin system, stimulates ovulation. In the classic renin-angiotensin 
system, angiotensinogen is cleaved by renin to form angiotensin I, which is then converted to AIl by angiotensinconverting enzyme (ACE). AIl is then rapidly cleaved to angiotensin III and other fragments by angiotensinase. It was originally thought that the renin-angiotensin system was unique to renal tissues; however, it has been shown to occur in numerous other tissues including the ovary. In the ovary, this system modulates diverse aspects of ovarian physiology, such as angiogenesis (Pepperell et al., 1994), follicular growth (Yoshimura et al., 1996a), atresia (Feral et al., 1995; Yamada et al., 1996), oocyte maturation (Pepperell et al., 1994), follicular rupture and oocyte release (Pellicer et al., 1988; Kuo et al., 1991; Peterson et al., 1993a; Pepperell et al., 1994). Oocyte release was inhibited when the AII receptor antagonists saralasin or PD123319 were injected into gonadotrophin-primed rats (Pellicer et al., 1988) or added to the culture media of in vitro perfused rabbit (Kuo et al., 1991; Yoshimura et al., 1996b) and rat (Peterson et al., 1993a) ovaries.

Although the mechanisms by which LH stimulates intracellular ovarian metalloproteinase production are uncertain, it is well documented that control of proteolytic enzyme activity in the extracellular space is regulated by metalloproteinase inhibitors. Two classes of metalloproteinase inhibitors are generally recognized, both of which are present in the ovary. The first class is the $\alpha_{2}$-macroglobulins, which are large serum-borne inhibitors including $\alpha_{2}$-macroglobulin $\left(\mathrm{MW}=720000\right.$ ) and $\alpha_{1}$-inhibitor-3 (MW $\left.=200000\right)$. The second class is the tissue-derived inhibitors, such as the tissue inhibitors of metalloproteinases, TIMP-1 (MW $=29000)$, TIMP-2 $(\mathrm{MW}=23000)$ and TIMP-3 $(\mathrm{MW}=21000)$ (Matrisian, 1990; Birkedal-Hansen et al., 1993). The TIMPs differ in their mode of action and selectivity for the different members of the metalloproteinase family. For example, TIMP-1 and TIMP-2 are secreted and found in the extracellular space, whereas TIMP-3 is secreted and bound to the extracellular matrix (Matrisian, 1990; Leco et al., 1994). In the ovary, the expression and the activity of metalloproteinase inhibitors are stimulated by the LH surge (Mann et al., 1991; Zhu and Woessner, 1991). Since LH induces both calcium release and the OVRAS, and since both of these messenger systems may stimulate ovulation, the purpose of the present study was to examine the regulation of metalloproteinase inhibitors and steroidogenesis by calcium and the renin-angiotensin system. This goal was accomplished by using in vitro and in vivo models with various treatments that stimulate changes in calcium, such as A23187, or regulate the OVRAS system by mimicking or inhibiting angiotensin action, such as AII or the AII receptor antagonist saralasin, respectively. The present study focused on TIMP-1 because it is induced by the LH surge and increases during the periovulatory period (Mann et al., 1991), whereas TIMP-2 is not stimulated by the LH surge and appears to be constitutively expressed during the follicular and ovulatory periods (Smith et al., 1995, T. E. Curry, unpublished observation).

\section{Materials and Methods}

\section{Materials}

Sprague-Dawley female rats were obtained from Harlan Sprague-Dawley, Inc. (Indianapolis, IN). Pregnant mares' serum gonadotrophin (PMSG), human chorionic gonadotrophin (hCG), the calcium ionophore A23187, human angiotensin II, and $\left(\mathrm{Sar}^{1}, \mathrm{Val}^{5}, \mathrm{Ala}^{8}\right)$-angiotensin II (saralasin) were purchased from Sigma Chemical Co. (St Louis, MO). Ham's DMEM (Dulbecco's Modified Eagle's medium): F12 was acquired from Gibco (Grand Island, NY). Gentamycin was obtained from Gensia Pharmaceuticals, Inc. (San Diego, CA). Sterile Falcon multiwell tissue culture plates were purchased from Becton Dickinson Co. (Lincoln Park, NJ). Ovine luteinizing hormone (oLH-25) was a gift from the National Institute of Diabetes, Digestive and Kidney Disease (NIDDK), National Hormone and Pituitary Program (Baltimore, MD). Azocoll was purchased from Calbiochem (La Jolla, CA). Nytran membranes were acquired from Schleicher and Schuell (Keene, NH). Random primer labelling kits were obtained from Gibco BRL (Gaithersburg, MD). $\left[\alpha_{-}{ }^{32} \mathrm{P}\right]-\mathrm{dCTP}$ was purchased from New England Nuclear (Boston, MA). Coat-A-Count kits for radioimmunoassay were acquired from Diagnostic Products Corporation (Los Angeles, CA).

\section{Tissue collection for culture of granulosa cells}

Immature female Sprague-Dawley rats were housed in controlled environmental conditions under the care and supervision of a licensed veterinarian. Rats were maintained on a $14 \mathrm{~h}$ light: $10 \mathrm{~h}$ dark cycle and provided with water and rat chow ad libitum. All animal procedures for these experiments were approved by the University of Kentucky Institutional Animal Care and Use Committee.

Rats were injected s.c. with 20 i.u. PMSG at 23 days of age to induce proliferation of granulosa cells and follicular development. Forty-eight hours later, animals were killed by cervical dislocation; ovaries were removed and trimmed, and granulosa cells were collected.

\section{Culture of granulosa cells}

Granulosa cells were isolated from preovulatory rat follicles as routinely performed in our laboratory (Mann et al., 1991). Briefly, the ovaries were trimmed of adnexa and placed into

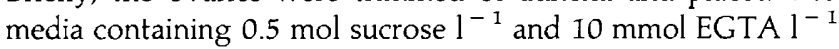
for $20 \mathrm{~min}$. The sucrose:EGTA treatment disrupts the granulosa cell gap junctions facilitating cell collection. The follicles were punctured repeatedly with a $26 \mathrm{G}$ needle and the granulosa cells were gently expressed, pooled, and pelleted by centrifugation $(10 \mathrm{~min}, 600 \mathrm{~g}$ ). Cell viability as determined using trypan blue exclusion was $50-55 \%$. Cells $\left(1 \times 10^{6} \mathrm{ml}^{-1}\right)$ were cultured in wells with $1.0 \mathrm{ml}$ Ham's DME:F12 containing HEPES $(15 \mathrm{mmol}$ $\left.\mathrm{I}^{-1}\right)$, sodium bicarbonate $\left(1.2 \mathrm{mg} \mathrm{ml}^{-1}\right), 1 \%(\mathrm{w} / \mathrm{v}) \mathrm{BSA}$, and gentamycin $\left(50 \mu \mathrm{g} \mathrm{ml}^{-1}\right)$. The cells were incubated for $24 \mathrm{~h}$ in the presence or absence of $\mathrm{LH}\left(100 \mathrm{ng} \mathrm{ml}^{-1}\right)$ and treatments which included the calcium ionophore A23187 $(0-100 \mu \mathrm{mol}$ $\left.\mathrm{l}^{-1}\right)$, angiotensin II $\left(0-10000 \mathrm{nmol} \mathrm{l}^{-1}\right)$, or the AII receptor antagonist saralasin $\left(1 \mu \mathrm{mol} \mathrm{l}{ }^{-1}\right)$. A control culture without treatment was included in every experiment. At the end of the $24 \mathrm{~h}$ incubation, the culture media were collected and centrifuged $(600 \mathrm{~g})$ for $10 \mathrm{~min}$ to pellet the granulosa cells. The media was then frozen at $-70^{\circ} \mathrm{C}$ until assayed for inhibitor 
activity and progesterone. Cell viability at the end of the $24 \mathrm{~h}$ culture was comparable irrespective of the culture treatment and was approximately $40 \%$.

\section{Assay of metalloproteinase inhibitor}

The inhibitor assay is a colorimetric assay based on the inhibition of a uterine neutral matrix metalloproteinase, matrilysin, as described by Mann et al. (1991). Metalloproteinase inhibitors present in the culture media conditioned with granulosa cells inhibit the digestion of the colorimetric Azocoll substrate by matrilysin, which is then quantitated spectrophotometrically.

A sufficient volume of the uterine matrilysin to yield a change in absorbance of 0.2 (approximately $10 \mu \mathrm{l}$ matrilysin, equivalent to 0.4 PUK units of pronase, Calbiochem) was added to $100 \mu \mathrm{l}$ conditioned granulosa cell media and brought to a total volume of $400 \mu \mathrm{l}$ with assay buffer $(50 \mathrm{mmol}$ Tris- $\mathrm{HCl}$ $1^{-1}, 10 \mathrm{mmol} \mathrm{CaCl}_{2} \mathrm{l}^{-1}, 0.2 \mathrm{~mol} \mathrm{NaCl} \mathrm{l}{ }^{-1}, 0.05 \%(\mathrm{w} / \mathrm{v})$ sodium azide, and $0.167 \%(\mathrm{w} / \mathrm{v}) \mathrm{Brij}, \mathrm{pH} 7.5)$. The assay was then preincubated for $1 \mathrm{~h}$ at $37^{\circ} \mathrm{C}$. After the incubation, $1 \mathrm{mg}$ of Azocoll suspended in $850 \mu \mathrm{l}$ of assay buffer was added to each sample and incubated at $37^{\circ} \mathrm{C}$ for $18 \mathrm{~h}$. The inhibition of the uterine matrilysin by granulosa cell-derived inhibitors was quantitated by measuring the absorbance at $520 \mathrm{~nm}$. Inhibitor activity is expressed as the change in inhibition compared with media from cells cultured for $24 \mathrm{~h}$ in the absence of any treatment (i.e. control culture).

\section{Tissue collection for northern blot analysis}

For determining the effect of the AII antagonist, saralasin, on ovarian mRNA encoding TIMP-I and steroidogenesis, ovaries and serum were collected from rats that were treated as follows. Immature female rats (23-day-old) were injected s.c. with 20 i.u. PMSG and 48 h later were injected s.c. with 10 i.u. hCG. Rats were then injected i.p. with $200 \mu 10 \mathrm{mmol}$ saralasin $\mathrm{l}^{-\mathrm{I}}$ at $\mathrm{I}$ or $3 \mathrm{~h}$ after hCG injection. A separate group of animals received an injection of vehicle only (no saralasin treatment) at 1 or $3 \mathrm{~h}$ after hCG administration. Rats were killed by decapitation at $0,4,8$ and $12 \mathrm{~h}$ after hCG injection. Serum was collected, and ovaries were removed. Both ovaries from one animal were used for northern blot analysis, while serum was stored at $-70^{\circ} \mathrm{C}$ until assayed by radioimmunoassay.

\section{Northern blot analysis}

Total RNA was isolated from rat ovaries with an acid guanidinium thiocyanate-phenol-chloroform mixture as described by Chomczynski and Sacchi (1987). RNA samples (20 $\mathrm{gg}$ per lane) were subjected to electrophoresis at $25 \mathrm{~V}$ through a $1 \%$ agarose gel containing $2.2 \mathrm{~mol}$ formaldehyde $1^{-1}$ and transferred to a nytran membrane. A mouse cDNA encoding TIMP-I (a generous gift from. D. Edwards, University of Calgary, Calgary, Alberta) was used to identify and quantify mRNA encoding TIMP-1 transcripts. The cDNA probe for TIMP-I was prepared by random primer labelling of a 825 bp fragment of cDNA encoding TIMP-I excised with BamHI and EcoRV as recommended by Gibco BRL. The
cDNA probe was labelled using $\left[\alpha-{ }^{32} \mathrm{P}\right] \mathrm{dCTP}$ and each hybridization contained $6.6 \times 10^{6}$ d.p.m. cDNA encoding TIMP-I ml ${ }^{-1}$ hybridization solution. Blots were visualized by autoradiography and were analysed with an LKB Ultroscan densitometer to calculate the relative mRNA content. Analyses were performed on samples from four different animal experiments $(n=4)$ and each experiment was performed on both ovaries from one animal per treatment. Values were normalized to the $28 \mathrm{~S}$ ribosomal RNA.

\section{Radioimmunoassay}

Steroid concentration was determined by radioimmunoassay using commercial Diagnostic Products Corporation (DPC) Coat-A-Count kits as recommended by the manufacturer. The Coat-A-Count kits are direct, solid phase ${ }^{125} \mathrm{I}$ radioimmunoassay kits previously validated for use in rats (Jones et al., 1987). Progesterone was assayed in the media of cultured granulosa cells, while both progesterone and oestradiol were assayed in serum collected from female rats. All assays were performed in duplicate. Culture media or serum were incubated with primary antibody for $3 \mathrm{~h}$ at room temperature. Samples were decanted, counted, and the steroid concentration was determined. Steroid concentration is expressed as change from a control cell culture for the granulosa cell experiments or as the raw data in rat serum from the experiments in vivo. The sensitivities of the oestradiol and progesterone assays were $8 \mathrm{pg} \mathrm{ml} \mathrm{m}^{-1}$ and $30 \mathrm{pg} \mathrm{ml}-1$, respectively. The intra- and interassay coefficients of variation were $5.4 \%$ and $9.4 \%$ for oestradiol and $4.7 \%$ and $8.9 \%$ for progesterone, respectively.

\section{Statistical analyses}

In the granulosa cell cultures, data are expressed as the change in inhibition or change in progesterone concentration compared with the control cultures \pm SEM. Each experiment was performed 3-8 times in duplicate. Homogeneity of variance was tested with Bartlett's test (Zar, 1974) before performing a repeated measures ANOVA (Mendenhall et al., $1977)$ to test for differences $(P<0.05)$ in inhibitor activity or progesterone production between treatment concentrations in the presence or absence of $\mathrm{LH}$. The repeated measure was derived from the duplicate culture subsequently assayed in duplicate. In the in vivo experiments, the data on the expression of mRNA encoding TIMP-1 and the serum concentrations of steroid were analysed by a one-way ANOVA. The duplicate values for the steroid concentrations were averaged before being used for the one-way ANOVA. Comparisons for the in vivo experiments were made to the vehicle treatment at the corresponding time point. If significance was obtained with the repeated measures or one-way ANOVA, the StudentNeuman-Keuls procedure was used to test for differences between the means for the various groups (Zar, 1974).

\section{Results}

Effect of A23187 on metalloproteinase inhibitor activity and progesterone production

Granulosa cells were incubated for $24 \mathrm{~h}$ with increasing concentrations of A23187 $\left(0-100 \mu \mathrm{mol} \mathrm{l}^{-1}\right)$ in the presence or 


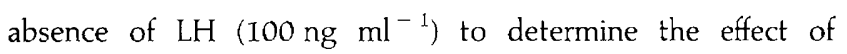
A23187 on metalloproteinase inhibitor activity and progesterone production. For metalloproteinase inhibitor activity, there was $16.8 \pm 1.9 \%$ inhibition of the matrilysin activity in a $100 \mu \mathrm{l}$ aliquot of the control conditioned culture media. This represents the amount of inhibitor activity in cells that were cultured for $24 \mathrm{~h}$ without treatment (absence of A23187 and absence of $\mathrm{LH})$. The addition of $\mathrm{LH}$ to the culture media stimulated inhibitor activity $3.04 \pm 0.4 \%$ compared with the control cultures. Increasing concentrations of A2.3187 in the absence of LH resulted in a decrease in inhibitor activity (Fig. Ia), particularly at higher concentrations of 10 and $100 \mu \mathrm{mol}^{-1}$ (decrease to $33 \pm 7$ and $31 \pm 5 \%$ of the control culture value, respectively). In the presence of both $\mathrm{A} 23187$ and $\mathrm{LH}$, inhibitor activity decreased as A23187 concentrations increased (Fig. 1a). Again, the higher concentrations of A23187 (10 and $100 \mu \mathrm{mol} 1^{-1}$ ) had the most marked effect on metalloproteinase inhibitor activity (decrease to $31 \pm 7$ and $32 \pm 7 \%$ of the control culture, respectively).

The mean progesterone concentration in the control culture media was $1.14 \pm 0.24 \mathrm{ng} \mathrm{ml}^{-1}$. The addition of $\mathrm{LH}$ to the culture media elicited a $20.30 \pm 4.85$-fold increase in mean progesterone concentration with respect to the control culture. Addition of low concentrations of A23187 (i.e. 0.1 and $1.0 \mu \mathrm{mol} L^{-1}$ ) to cells cultured in the absence of LH had no effect on progesterone production, whereas higher doses of A23187 (i.e. 10 and $100 \mu \mathrm{mol} \mathrm{l}^{-1}$ ) stimulated progesterone production by $2.96 \pm 0.57$ and $5.53 \pm 0.45$ times, respectively (Fig. Ib). In contrast to cells cultured without LH, A23187 added to LH-stimulated cells decreased progesterone production at concentrations of 1 and $10 \mu \mathrm{mol} 1^{-1}$, whereas $100 \mu \mathrm{mol}$ A23187 $1^{-1}$ had no effect on progesterone production (Fig. Ib).

\section{Effect of AII on metalloproteinase inhibitor activity and progesterone production}

Granulosa cells were incubated for $24 \mathrm{~h}$ with increasing concentrations of AII $\left(0-10000 \mathrm{nmol} \mathrm{l}^{-1}\right)$ in the presence or absence of $\mathrm{LH}$ ( $100 \mathrm{ng} \mathrm{ml}^{-1}$ ), to determine the effect of AII on metalloproteinase inhibitor activity and progesterone production. For metalloproteinase inhibitor activity, there was $23.4 \pm 5.6 \%$ inhibition of the matrilysin activity in the control culture media (i.e. cells cultured without AII in the absence of LH). The addition of LH stimulated inhibitor activity by $2.25 \pm 0.24$ times compared with control cultures (Fig. 2a). Increasing concentrations of All in the absence of LH did not change inhibitor activity compared with the control culture. Similarly, in the presence of LH, AII did not change inhibitor activity with respect to that of $\mathrm{LH}$ alone (Fig. 2a).

The mean progesterone concentration in the control culture media was $8.94 \pm 2.15 \mathrm{ng} \mathrm{ml}^{-1}$. The addition of LH to the culture media elicited a $17.25 \pm 3.22$-fold increase in mean progesterone concentration compared with the control culture. The mean concentration of progesterone did not change significantly after addition of increasing doses of All to cells cultured in the absence or presence of LH (Fig. 2b).
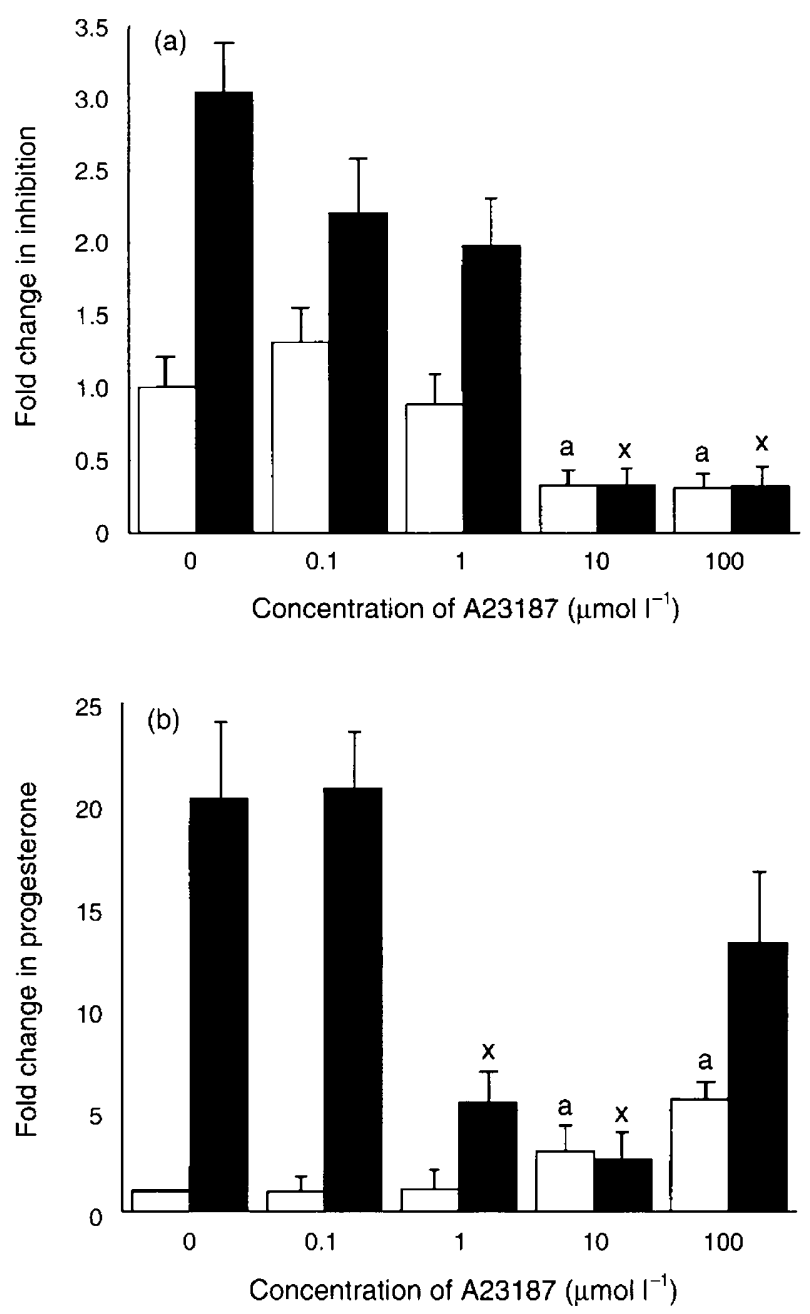

Fig. 1. Effect of increasing concentrations of A23187 on granulosa cell-derived metalloproteinase inhibitor activity and progesterone synthesis. Granulosa cells $\left(I \times 10^{6}\right.$ cells ml $\left.^{-1}\right)$ were cultured for $24 \mathrm{~h}$ in the presence of increasing doses of A23187 $\left(0-100 \mu \mathrm{mol} \mathrm{I}{ }^{-1}\right)$ with ( activity was measured in the media and expressed as the fold change in inhibition with respect to a control cell culture (mean \pm SEM, $n=4$ experiments in duplicate). (b) Progesterone concentration in the media was determined and expressed as change in progesterone concentration with respect to the control cell culture (mean $\pm \mathrm{SEM}, n=5$ experiments in duplicate). ${ }^{\text {a }}$ Significant difference $(P<0.05)$ between cells cultured with A23187 in the absence of LH versus the control culture (that is, A23187 concentration $=0$ ); ${ }^{x}$ significant difference $(P<0.05)$ in cells cultured with LH plus A23187 versus the LH-treated culture.

\section{Effect of the AII antagonist, saralasin, on metalloproteinase inhibitor activity and progesterone production}

Saralasin, an angiotensin II receptor antagonist, was added to the cell culture to determine whether endogenous AIl was responsible for ovarian metalloproteinase inhibitor activity or progesterone production. Granulosa cells were cultured in the presence or absence of LH $\left(100 \mathrm{ng} \mathrm{ml}^{-1}\right)$, AII $\left(1 \mu \mathrm{mol} \mathrm{l}^{-1}\right)$, or saralasin $\left(1 \mu \mathrm{mol} \mathrm{l}{ }^{-1}\right)$. For metalloproteinase inhibitor activity, there was $35.5 \pm 2.8 \%$ inhibition in the control culture media. LH elicited a $1.57 \pm 0.06$-fold increase in inhibitor activity 

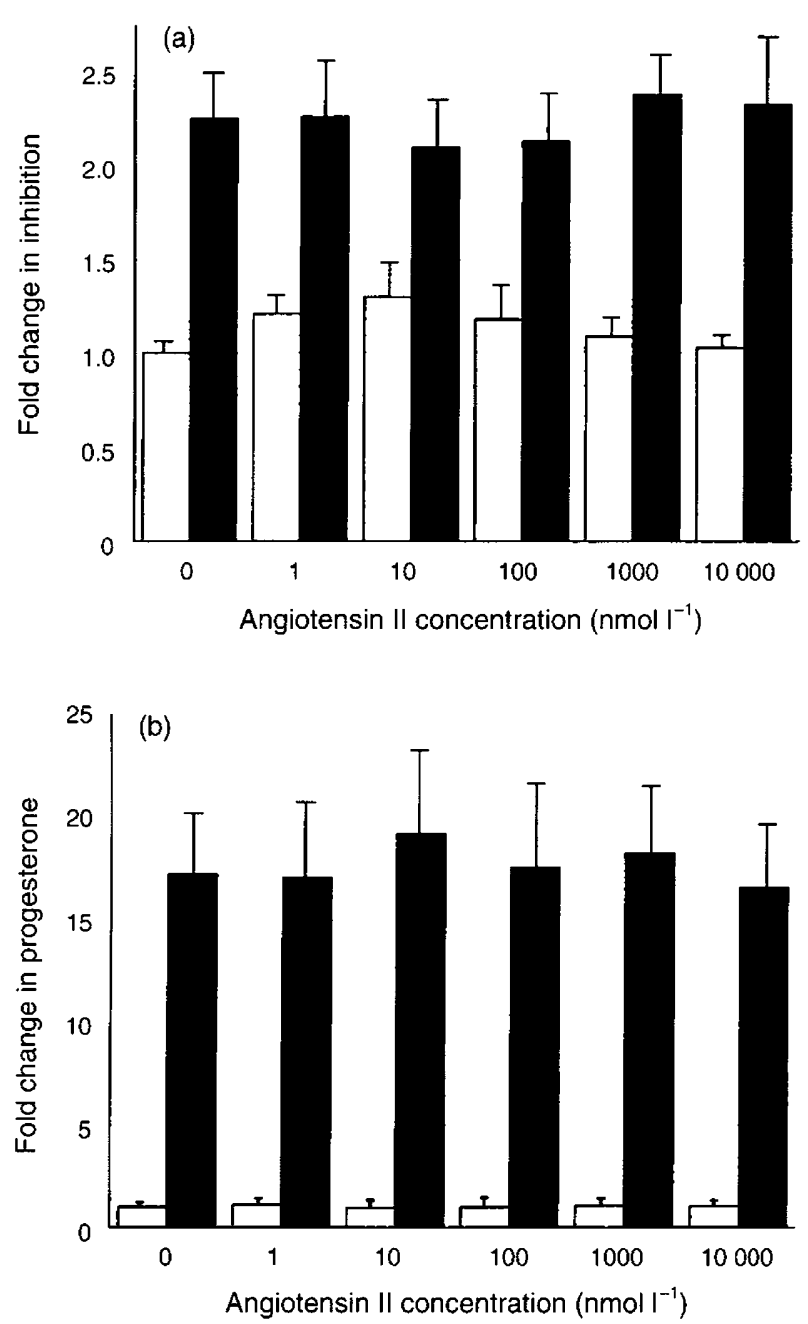

Fig. 2. Effect of increasing angiotensin II concentrations on granulosa cell-derived metalloproteinase inhibitor activity and progesterone synthesis. Granulosa cells $\left(1 \times 10^{6}\right.$ cells $\left.\mathrm{ml}^{-1}\right)$ were cultured for $24 \mathrm{~h}$ in the presence of increasing doses of angiotensin II $(0-10000 \mathrm{nmol}$ $\mathrm{l}^{-1}$ ) with (a) or without ( $\square$ ) LH (100 $\mathrm{ng} \mathrm{ml}^{-1}$ ). (a) Metalloproteinase inhibitor activity was measured in the media and expressed as the change in inhibition with respect to a control cell culture (mean \pm SEM, $n=4$ experiments in duplicate). (b) Progesterone concentration in the media was determined and expressed as change in progesterone concentration with respect to the control cell culture (mean \pm SEM, $n=5$ experiments in duplicate). No significant differences were observed with angiotensin II treatment.

compared with control cultures. There were no changes in inhibitor activity versus control values upon addition of saralasin, AII, or both in the absence of LH (Fig. 3a). Furthermore, the addition of saralasin, AII, or both in the presence of LH elicited no changes in inhibitor activity with respect to the $\mathrm{LH}$ values (Fig. 3a).

For progesterone production, there was a mean progesterone concentration of $7.00 \pm 1.79 \mathrm{ng} \mathrm{ml}^{-1}$ in the control culture media. The addition of LH elicited a $7.73 \pm 0.94$-fold increase in progesterone concentration over control cultures. There was no change in progesterone concentration versus control values upon the addition of saralasin, AII, or both in the absence or presence of LH (Fig. 3b).
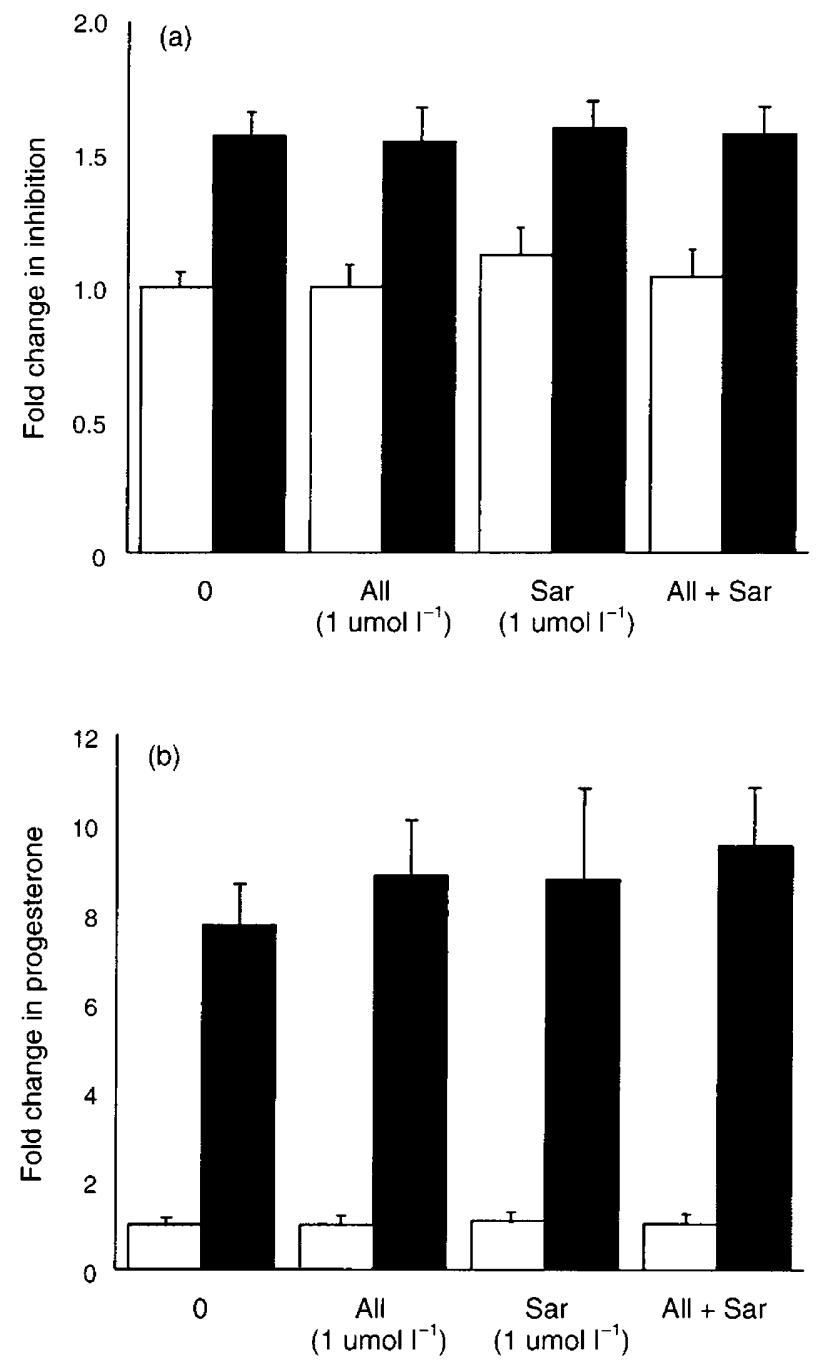

Fig. 3. Effect of saralasin (Sar) on granulosa cell-derived metalloproteinase inhibitor activity and progesterone synthesis in rat ovaries. Granulosa cells $\left(1 \times 10^{6}\right.$ cells $\left.\mathrm{ml}^{-1}\right)$ were cultured for $24 \mathrm{~h}$ in the presence of angiotensin II (AII), saralasin, or AII plus saralasin with (ם) or without ( $\square$ ) LH (100 $\mathrm{ng} \mathrm{ml}^{-1}$ ). (a) Metalloproteinase inhibitor activity was measured in the media and expressed as the change in inhibition with respect to a control cell culture (mean $\pm \operatorname{SEM}, n=4$ experiments in duplicate). (b) Progesterone concentration in the media was determined and expressed as change in progesterone concentration with respect to the control cell culture (mean $\pm \mathrm{SEM}, n=5$ experiments in duplicate). No significant differences were observed with saralasin treatment.

Effect of saralasin administration in vivo on TIMP-1 expression and steroidogenesis

The effect of the AII antagonist, saralasin, on ovarian mRNA encoding TIMP-1 and steroidogenesis was determined by collecting ovaries and serum from rats treated with $200 \mu \mathrm{l}$ of $10 \mathrm{mmol}$ saralasin $\mathrm{l}^{-1}$ or vehicle at $\mathrm{I}$ or $3 \mathrm{~h}$ after $\mathrm{hCG}$ injection. Rats were killed at $0,4,8$ and $12 \mathrm{~h}$ after hCG injection. For TIMP-I expression, a single transcript of approximately 900 base pairs was detected (Fig. 4). After hCG treatment, TIMP-1 expression increased by 1.70 times at $4 \mathrm{~h}$, by 3.34 times at $8 \mathrm{~h}$, and by 2.95 times at $12 \mathrm{~h}$ compared with 


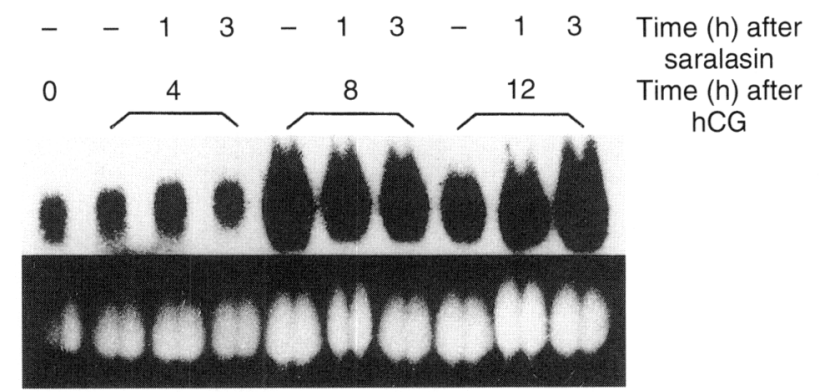

Fig. 4. Northern blot analysis of ovarian mRNA encoding tissue inhibitor of metalloproteinase I (TIMP-I) following saralasin administration during the periovulatory period. Rats were injected with 20 i.u. PMSG followed by 10 i.u. hCG $48 \mathrm{~h}$ later. Animals were then injected i.p. with $200 \mu \mathrm{l} 10 \mathrm{mmol}$ saralasin $\mathrm{l}^{-1}$ at $\mathrm{I}$ or $3 \mathrm{~h}$ after hCG injection. Rat ovaries were collected at $0,4,8$ and $12 \mathrm{~h}$ after hCG. RNA samples ( $20 \mu \mathrm{g}$ per lane) were prepared, isolated, and hybridized with a full-length mouse cDNA probe for TIMP-1. A single transcript of approximately $900 \mathrm{bp}$ is present (upper panel) in the representative blot $(n=4)$. The corresponding ethidium bromide stained gel of the $28 \mathrm{~S}$ ribosomal RNA is depicted in the lower panel. Changes in TIMP-1 expression were normalized to the $28 \mathrm{~S}$ rRNA before comparison with the $\mathrm{O} \mathrm{h}$ hCG group.

that in ovaries collected at the time of hCG (i.e. $0 \mathrm{~h}$, Table 1). Administration of saralasin at 1 or $3 \mathrm{~h}$ after hCG administration had no effect on TIMP-I expression compared with that of animals receiving vehicle only (Table 1 ).

For progesterone production, the mean progesterone concentration in rats not receiving an injection of hCG or saralasin was $5.05 \pm 1.24 \mathrm{ng} \mathrm{ml}^{-1}$ (Table 1). Progesterone concentrations increased in rats killed at 4,8 and $12 \mathrm{~h}$ after hCG injection. The administration of saralasin at I or $3 \mathrm{~h}$ after hCG injection did not change progesterone concentration at any time point (Table 1).

For oestradiol production, the mean oestradiol concentration in rats receiving no injection of hCG or saralasin was $611.9 \pm 122.4 \mathrm{pg} \mathrm{ml}^{-1}$ (Table 1). Oestradiol concentrations declined at 4,8 and $12 \mathrm{~h}$ after hCG injection. The administration of saralasin at 1 or $3 \mathrm{~h}$ after hCG did not change oestradiol concentration at any time point (Table 1).

\section{Discussion}

The present data demonstrate that intracellular calcium regulates ovarian metalloproteinase inhibitor activity. In contrast, angiotensin II appears to have no effect on granulosa cellderived inhibitor activity, steroidogenesis, or periovulatory ovarian TIMP-I expression. Calcium ionophores, such as A23187, may alter the activity of calcium in subcellular compartments by specifically affecting the transmembrane calcium flux with little disturbance to other transmembrane channels (Pfieffer et al., 1978). Addition of A23187 to cultured granulosa cells in the present study decreased metalloproteinase inhibitor activity two- to threefold in both unstimulated (i.e. control) and LH-treated cells. This inhibition of metalloproteinase inhibitor activity by A23187 demonstrates the importance of calcium in regulating inhibitor activity
The role of calcium in the process of LH-stimulated ovulation is controversial. A possible role for calcium in follicular rupture has been demonstrated using the calcium chelators EDTA (Wallach et al., 1978) and EGTA (Kitai et al., 1985), or calcium channel blockers, such a verapamil (Martin and Talbot, 1981). For example, addition of EDTA or EGTA to hCGstimulated, perfused rabbit ovaries completely inhibited oocyte release in $50-80 \%$ of the ovaries and also reduced the number of ova that ovulated (Wallach et al., 1978; Kitai et al., 1985). However, conflicting reports question the role of calcium in ovulation. Although intrabursal administration of verapamil inhibits oocyte release in hamsters (Martin and Talbot, 1981), addition of verapamil to the media of perfused rabbit ovaries had no effect on hCG-stimulated ovulation (Kitai $e t$ al., 1985). In contrast to the studies with EDTA and EGTA, ovulation does occur in rabbit ovaries perfused in calcium- and magnesium-free media in the absence of observed smooth muscle contractions (Kobayashi et al., 1984). However, the time interval from an hCG stimulus to ovulation is accelerated (occurring within $2 \mathrm{~h}$ ) and the oocytes released are immature. Kobayashi et al. (1984) proposed that deletion of calcium and magnesium from the media "... fosters degradation of the follicle wall by weakening basement membranes".

Although the role of calcium in the ovulatory process remains controversial, the findings of the present study indicate that calcium may influence periovulatory proteolysis by regulating metalloproteinase inhibitor activity. It has been reported that calcium interacts synergistically with activators of protein kinase $\mathrm{C}$ to induce metalloproteinase expression in human cervical fibroblasts (Rodland et al., 1992). Although it is unknown whether calcium can stimulate ovarian metalloproteinase activity, Espey and Coons (1976) demonstrated that EDTA inhibits follicular degradation of reconstituted collagen in vitro. Their findings are consistent with reports that EDTA inhibits collagenase activity from skin fibroblasts (Werb and Burleigh, 1974) and rat uterus (Woessner and Ryan, 1973). Thus, it is possible that calcium stimulates collagenase production or activity or both factors while also decreasing metalloproteinase inhibitor activity. The net effect of such a paradigm would be an increase in follicular collagenase action, which would weaken the apical wall and thereby facilitate follicular rupture. However, the findings of a decrease in inhibitor activity in response to $\mathrm{A} 23187$ in the presence of $\mathrm{LH}$ are inconsistent with the proposed mechanism of $\mathrm{LH}$ action on ovarian inhibitor activity. It has been suggested that the LH surge stimulates a preovulatory increase in both metalloproteinases and metalloproteinase inhibitors. Degradation of the follicular wall may result either from an excess of the enzyme to inhibitor at the follicular apex (Zhu and Woessner, 1991) or from compartmentalization of the enzyme to the apex and the inhibitors to different compartments such as the granulosa cell layer (Mann et al., 1991). Upon follicular rupture, there is a loss of this compartmentalization such that the enzymes and inhibitors can interact and turn off further proteolysis. In the present study, it is possible that the calcium stimulation in response to A23187 may supersede the physiological release induced by $\mathrm{LH}$, that the calcium influx stimulated by A23187 does not mimic the intracellular release activated by $\mathrm{LH}$ on induction of inhibitor activity as at least two types of calcium channels are present in granulosa cells 
Table 1. Effect of saralasin administration in vivo on expression of tissue inhibitor of metalloproteinase 1

(TIMP-1) and steroidogenesis in rat ovaries

\begin{tabular}{lcccc}
\hline $\begin{array}{l}\text { Saralasin injection } \\
\text { (h after hCG) }\end{array}$ & $\begin{array}{c}\text { Time of death } \\
\text { (h after hCG) }\end{array}$ & $\begin{array}{c}\text { mRNA encoding } \\
\text { TIMP-1 }\end{array}$ & $\begin{array}{c}\text { Progesterone } \\
\text { (ng ml }{ }^{-1} \text { ) }\end{array}$ & $\begin{array}{c}\text { Oestradiol } \\
\left(\mathrm{pg} \mathrm{ml}^{-1}\right)\end{array}$ \\
\hline No injection & 0 & 1.00 & $5.05 \pm 1.24$ & $611.9 \pm 122.4$ \\
Vehicle only & 4 & $1.70 \pm 0.73$ & $21.07 \pm 1.24$ & $495.4 \pm 97.0$ \\
$\quad$ I & 4 & $1.53 \pm 0.07$ & $28.19 \pm 3.74$ & $409.4 \pm 49.9$ \\
3 & 4 & $1.46 \pm 0.24$ & $26.71 \pm 2.10$ & $368.4 \pm 56.4$ \\
Vehicle only & 8 & $3.34 \pm 0.17$ & $70.79 \pm 5.94$ & $125.8 \pm 23.8$ \\
I & 8 & $4.03 \pm 0.72$ & $80.84 \pm 11.87$ & $130.7 \pm 33.9$ \\
3 & 8 & $4.47 \pm 0.74$ & $97.10 \pm 11.39$ & $130.2 \pm 29.1$ \\
Vehicle only & 12 & $2.95 \pm 0.15$ & $58.30 \pm 6.58$ & $79.4 \pm 11.3$ \\
1 & 12 & $3.35 \pm 0.22$ & $60.35 \pm 6.91$ & $70.5 \pm$ \\
3 & 12 & $3.47 \pm 0.34$ & $47.01 \pm 3.84$ & $56.7 \pm 10.9$ \\
\hline
\end{tabular}

Ovaries were collected at various times after hCG treatment with or without saralasin. RNA was extracted and analysed for TIMP-1 expression. The amount of mRNA encoding TIMP-1 was normalized to the $28 \mathrm{~S}$ ribosomal RNA and expressed as the change in the digitized value from the $\mathrm{O} h$ time point (mean $\pm \mathrm{SEM}, n=4$ ). Serum was collected from rats treated as indicated and progesterone and oestradiol were determined by radioimmunoassay of the serum. Data are expressed as concentration of steroid (mean \pm SEM, $n=4-6$ observations).

(Wan et al., 1996), or that there are divergent effects of calcium depending upon the intracellular concentration as previously reported for inositol phosphate (Bezprozvanny et al., 1991). The presence of two channels within the same cell with different responses to calcium and ligand sensitivities may provide for complex patterns of calcium action (Bezprozvanny et al., 1991) and may result in a discordance in the regulation of inhibitor activity by calcium versus LH observed in the present study.

The ovarian renin-angiotensin system (OVRAS) modulates ovarian angiogenesis, atresia, steroidogenesis, oocyte maturation, ovulation, and polycystic ovarian disease (reviewed in Lightman et al., 1989; Morris and Paulson, 1994; Pepperell et al., 1994). This role for the OVRAS in ovarian physiology is supported by the finding of angiotensin receptors, ATI and AT2, in rat ovaries especially AT2 receptors in granulosa cells (Pucell et al., 1987, 1991). Furthermore, the role of angiotensin II in steroidogenesis is evident from reports that AII increases progesterone concentrations in luteinized rat granulosa cell cultures and increases concentrations of progesterone, testosterone and oestradiol in human granulosa-lutein cell cultures (Lightman et al., 1989) which can be blocked by coincubation with the AII receptor antagonist, saralasin. Other investigators have shown that hCG stimulates renin-like activity and AII production in the human (Peperell et al., 1994), bovine (Brunswig-Spickenheier et al., 1995), and rabbit ovary (Yoshimura et al., 1994). Ultimately, AII has been shown to be a mediator of $\mathrm{LH}$ action on oocyte maturation and ovulation (Pellicer ef al., 1988; Yoshimura et al., 1992; Peperell et al., 1994). Further support for AII in the ovulatory process stems from studies with saralasin, in which several investigators have shown that saralasin inhibits AII-induced ovulation (Kuo et al., 1991; Yoshimura et al., 1992, 1994, 1996b; Peterson et al., 1993a). In toto, these findings suggest that AII plays a role in follicular rupture.

Because of these previously mentioned findings and the observation that AII regulates MMPs and inhibitors in brain
(Olson et al., 1991), kidney (Matsusaka et al., 1996) and heart (Brilla et al., 1995), we were interested in determining whether AII could elicit a response in our granulosa cell culture model. As the present data show, addition of AII to cultured granulosa cells did not change inhibitor activity or progesterone production in the dose-response experiments. The lack of an AII response could have a biological basis or could be attributed to a lack of bioactivity of the AII preparation or stimulation of the granulosa cells by endogenous AII. Separate experiments demonstrated that AII added to cultured pituitary cells stimulated prolactin release thus confirming the biological potency of our AII (J. Hyde, unpublished observation). Saralasin was added to the cell culture to determine whether endogenous AII mediates inhibitor activity or steroidogenesis. In these experiments, saralasin did not alter inhibitor activity. Our findings indicate that AII does not have a biological effect on metalloproteinase inhibitor activity or steroidogenesis in rat granulosa cells cultured in serum-free conditions for $24 \mathrm{~h}$.

There is conflicting evidence about the role of the OVRAS in ovarian steroidogenesis between different species and even within the same species depending upon the experimental paradigm (Peperell et al., 1994; Li et al., 1995; Nielsen et al., 1995). In rats, AII stimulated oestradiol production by ovaries from PMSG-treated animals that had been sectioned into quarters (Pucell et al., 1987). In contrast, AII had no effect on basal or FSH-stimulated aromatase activity in granulosa cells from diethylstilboestrol (DES)-primed rats but had a mild stimulatory effect on progesterone (Pucell et al., 1988, 1991). Progesterone production was also stimulated by AII in luteinized rat granulosa cell cultures (Lightman $e t$ al., 1989). However, AII had no effect on progesterone production by granulosa cells from PMSG-primed rats (Pucell et al., 1987) but did stimulate progesterone in granulosa cells cultured for longer periods (that is 72 h, Usuki et al., 1993). Metalloproteinase inhibitor expression was examined in intact ovaries to determine whether the lack of an AII effect on granulosa cell steroidogenesis and inhibitor activity observed in the present study could be attributed to 
problems with cell culture or granulosa cell dissociation. Administration of saralasin in the present study using concentrations and paradigms reported by previous investigators (Pellicer et al., 1988) did not effect the expression of mRNA encoding TIMP-1 or the concentrations of oestradiol or progesterone.

Our data are supported by reports that question the role of AII in the ovulatory process. For example, Daud et al. (1989) were unable to repeat the previous findings of Pellicer et al. (1988) and inhibit ovulation with i.p. administration of saralasin. Using the ACE inhibitor captopril in rats, Peterson et al. (1993b) found no significant inhibition of ovulation or change in steroid production in vitro or in vivo in rats. Similarly, administration of captopril to perfused rabbit ovaries had no effect on ovulatory efficiency (Yoshimura et al., 1994). Therefore, we propose that AII is not involved in the regulation of metalloproteinase inhibitor activity associated with the breakdown of the ovarian connective tissue to induce ovulation.

In the present study, biological variation was observed between experiments in the responsiveness of granulosa cells to an LH stimulus. For example, in the A23187 and AII experiments, $\mathrm{LH}$ induced a 20.3 - and 17.3 -fold increase in progesterone production, whereas in the saralasin experiment, LH induced only a 7.7-fold increase in progesterone. We and others (Erickson, 1983) have noted such variation and have attributed this to subtle differences in animals or slight differences in methods of granulosa cell isolation, such as harvest time or time between isolation and hormonal treatment. The variability between granulosa cell experiments was normalized by expressing the data relative to the control culture in each experiment.

In summary, calcium may stimulate collagenase activity, decrease ovarian metalloproteinase inhibitor activity, and weaken the apical wall to aid in follicular rupture. In contrast, angiotensin II does not influence follicular rupture via the metalloproteinase-inhibitor ovulatory pathway.

The authors would like to acknowledge the assistance of C. Moore and V. Printz for their help with the radioimmunoassays and D. Chamberlain in the preparation of the manuscript. The authors would also like to thank the National Hormone and Pituitary Program for the gift of ovine luteinizing hormone. This work was supported by $\mathrm{NIH}$ HD23195.

\section{References}

Bezprozvanny I, Watras J and Ehrlich BE (1991) Bell-shaped calcium response curves of Ins $(1,4,5) \mathrm{P}_{3^{-}}$and calcium gated channels from endoplasmic reticulum of cerebellum Nature 351 751-754

Birkedal-Hansen H, Moore WGI, Boddenn MK, Windsor LJ, Birkedal-Hansen B, DeCarlo A and Engler JA (1993) Matrix metalloproteinases: a review Critical Reviews of Oral Biology and Medicine 4 197-250

Brilla CG, Rupp H, Funck R and Maisch B (1995) The renin-angiotensinaldosterone system and myocardial collagen matrix remodelling in congestive heart failure European Heart Journal Supplement O 107-109

Brunswig-Spickenheier B, Steinbach B and Mukhopadhyay AK (1995) Paracrine regulation of the bovine ovarian prorenin-renin-angiotensin system Advances in Experimental Medicine and Biology 377 399-406

Chomczynski P and Sacchi N (1987) Single-step method of RNA isolation by acid guanidinium thiocyanate-phenol-chloroform extraction Analyfical Biochemistry 162 156-159
Daud AI, Bumpus FM and Husain A (1989) Angiotensin II: does it have a direct obligate role in ovulation? Science 245 870-871

Erickson GF (1983) Primary cultures of ovarian cells in serum-free medium as models of hormone-dependent differentiation Molecular and Cellular Endocrinology $2921-49$

Espey LL and Coons PJ (1976) Factors which influence ovulatory degradation of rabbit ovarian follicles Biology of Reproduction 14 233-245

Espey LL and Lipner H (1994) Ovulation. In The Physiology of Reproduction pp 725-780 Eds E Knobil and JD Neill. Raven Press, New York

Feral C, Le Gall S and Leymarie P (1995) Angiotensin II modulates steroidogenesis in granulosa and theca in the rabbit ovary: its possible involvement in atresia European Journal of Endocrinology 133 747-753

Hylka VW and diZegera GS (1990) Granulosa cells from pig follicles of different sizes demonstrate maturational differences in their steroidogenic responses to FSH, calcium inophore A23187, and phorbol diester Journal of Reproduction and Fertility 89 181-191

Jones HM, Vernon MW and Rush ME (1987) Androgenic modulation of periovulatory FSH release in the rat Biology of Reproduction 37 268-276

Kitai H, Santulli R, Wright KH and Wallach EE (1985) Examination of the role of calcium in ovulation in the in vitro perfused rabbit ovary with use of ethyleneglycol-bis( $b$-aminoethyl ether)- $n, n^{\prime}$-tetraacetic acid and verapamil American Journal of Obstetrics and Gynecology 152 705-708

Kobayashi Y, Kitai H, Santulli R, Wright KH and Wallach EE (1984) Influence of calcium and magnesium deprivation on ovulation and ovum maturation in the perfused rabbit ovary Biology of Reproduction 31 287-295

Kuo TC, Endo K, Dharmarajan AM, Miyazaki T, Atlas SJ and Wallach EE (1991) Direct effect of angiotensin II on in vitro perfused rabbit ovary Journal of Reproduction and Fertility 92 469-474

Leco KJ, Khokha R, Pavloff N, Hawkes SP and Edwards DR (1994) Tissue inhibitor of metalloproteinases-3 (TIMP-3) is an extracellular matrixassociated protein with a distinctive pattern of expression of mouse cells and tissues Journal of Biological Chemistry 269 9352-9360

Li XM, Juorio AV and Murphy BD (1995) Angiotensin II interferes with steroidogenesis in porcine granulosa cells Biology of Reproduction $\mathbf{5 3}$ 791-799

Lightman A, Palumbo A, DeCherney AH and Naftolin F (1989) The ovarian renin-angiotensin system Seminars in Reproductive Endocrinology 7 79-87

Mann JS, Kindy MS, Edwards DR and Curry TE, Jr (1991) Hormonal regulation of matrix metalloproteinase inhibitors in rat granulosa cells and ovaries Endocrinology $128 \quad 1825-1832$

Martin GG and Talbot P (1981) Drugs that block smooth muscle contraction inhibit in vioo ovulation in hamsters Journal of Experimental Zoology 216 $483-491$

Matrisian LM (1990) Metalloproteinases and their inhibitors in matrix remodeling Trends in Genetics 6 121-125

Matsusaka T, Hymes J and Ichikawa I (1996) Angiotensin in progressive renal diseases: theory and practice Journal of the American Society of Nephrology 10 2025-43.

Mendenhall W, McClave JT and Ramey M (1977) Statistics for Psychology pp 298-362. Duxbury Press, North Scituate, MA

Morris RS and Paulson RJ (1994) Ovarian derived prorenin-angiotensin cascade in human reproduction Fertility and Sterility 62 1105-1114

Nielsen AH, Hagemann A, Svenstrup B, Nielsen J and Poulsen K (1995) Regulation of angiotensin II receptor expression in ovarian follicles. A review Advances in Experimental Medicine and Biology 377 407-410

Olson JA, Shiverick KT, Ogilvie S, Buhi WC and Raizada MK (1991) Angiotensin II induces secretion of plasminogen activator inhibitor 1 and a tissue metalloprotease inhibitor-related protein from rat brain astrocytes Proceedings of the National Academy of Sciences USA 88 1928-1932

Pellicer A, Palumbo A, DeCherney AH and Naftolin F (1988) Blockage of ovulation by an angiotensin antagonist Science 240 1660-1661

Pepperell JR, Nemith G, Roa L, Yamada Y, Palumbo A and Naftolin F (1994) Intraovarian regulation by the ovarian renin-angiotensin system Australian and New Zealand Journal of Obstetrics and Gynaecology 34 288-292

Peterson CM, Zhu C, Mukaida T, Butler TA, Woessner JF, Jr and LeMaire WJ (1993a) The angiotensin II antagonist saralasin inhibits ovulation in the perfused rat ovary American Journal of Obstetrics and Gynecology 168 242-245

Peterson CM, Morioka N, Zhu C, Ryan JW and LeMaire WJ (1993b) Angiotensin converting enzyme inhibitors have no effect on ovulation and ovarian steroidogeneis in the perfused rat ovary Reproductive Toxicology 7 131-135 
Pfieffer DR, Taylor RW and Lardy HA (1978) Ionophore A23187: cation binding and transport properties Annals of the New York Academy of Sciences $\mathbf{3 0 7}$ 402-423

Pucell AG, Bumpus FM and Husain A (1987) Rat ovarian angiotensin II receptors Journal of Biological Chemistry 262 7076-7080

Pucell AG, Bumpus, FM and Hussain A (1988) Regulation of angiotensin Il receptors in cultured rat ovarian granulosa cells by folliclestimulating hormone and angiotensin II Journal of Biological Chemistry 263 11 954-11961

Pucell AG, Hodges JC, Sen I, Bumpus FM and Husain A (1991) Biochemical properties of the ovarian granulosa cell type 2-angiotensin II receptor Endocrinology 128 1947-1959

Rodland KD, Lenormand P, Muldoon LL and Magun BE (1992) Regulation of transin/stromelysin and VL30 gene expression by intracellular calcium Journal of Investigative Dermatology 98 Supplement 12S-16S

Smith GW, McCrone S, Petersen SL and Smith MF (1995) Expression of messenger ribonucleic acid encoding tissue inhibitor of metalloproteinases-2 within ovine follicles and corpora lutea Endocrinology 136 570-576

Usuki S, Saitoh T, Saitoh M, Tanaka J, Kawakura Y, Usuki Y, Shinjo M and Kim S] (1993) Endothelin-renin-angiotensin-atrial natriuretic peptide system in ovaries: an intraovarian ERAANP system Journal of Cardiovascular Pharmacology 22 S207-210

Veldhuis JD and Demers LM (1986) An inhibitory role for the protein kinase C pathway in ovarian steroidogenesis Biochemical Journal 239 505-511

Wallach ED, Wright KH and Hamada Y (1978) Investigation of mammalian ovulation with an in vitro perfused rabbit ovary preparation American Journal of Obstetrics and Gynecology 132 728-738

Wan X, Desilets M, Soboloff J, Morris C and Tsang BJ (1996) Muscarinic activation inhibits $\mathrm{T}$-type $\mathrm{Ca}^{2+}$ current in hen granulosa cells Endocrinology $1372514-2521$
Welsh TH, Jones PB and Hsueh AJW (1984) Phorbol ester inhibition of ovarian and testicular steroidogenesis in vitro. Cancer Research 44 885-892

Werb Z and Burleigh MC (1974) A specific collagenase from rabbit fibroblasts in monolayer culture Biochemical Journal 137 373-385

Woessner JF, Jr and Ryan JN (1973) Collagenase activity in homogenates in the involuting rat uterus Biochimica et Biophysica Acta 309 397-405

Yamada T, Horiuchi M and Dzau VJ (1996) Angiotensin II type 2 receptor mediates programmed cell death in ovaries Proceedings of the National Academy of Sciences (USA) 93 156-160

Yoshimura Y, Karube M, Koyama N, Shiokawa S, Nanno T and Nakamura Y (1992) Angiotensin II directly induces follicle rupture and oocyte maturation in the rabbit FEBS Letters 307 305-308

Yoshimura Y, Koyama N, Karube M, Oda T, Akiba M, Yoshinaga A, Shiokawa S, Jinno $M$ and Nakamura $Y$ (1994) Gonadotropin stimulates ovarian reninangiotensin system in the rabbit Joumal of Clinical Investigation 93 180-I87

Yoshimura Y, Aoki N, Sueoka K, Miyazaki T, Kuji N, Tanaka M and Kobayashi T (1996a) Interactions between insulin-like growth factor-I (IGF-l) and the renin-angiotensin system in follicular growth and ovulation Journal of Clinical Investigation 98 308-316

Yoshimura Y, Karube M, Aoki H, Oda T, Koyama N, Nagai A, Akimoto $Y$, Hirano H and Nakamura $Y$ (1996b) Angiotensin II induces ovulation and oocyte maturation in rabbit ovaries via the AT2 receptor subtype Endocrinology 137 1204-1211

Zar JH (1974) Biostatistical Analysis pp 151-162. Prentice-Hall, Inc., Englewood Cliffs, NJ

Zhu C and Woessner JF, Jr (1991) A tissue inhibitor of metalloproteinases and alpha-macroglobulins in the ovulatory rat ovary. Possible regulators of collagen matrix breakdown Biology of Reproduction 45 334-342 